\title{
The Urgent Need for Queer and Feminist Hindu Theology
}

\author{
Brandon Graham, Vikram Sundarraman*
}

Nirangal Organization, India

Copyright $\mathrm{C} 2018$ by authors, all rights reserved. Authors agree that this article remains permanently open access under the terms of the Creative Commons Attribution License 4.0 International License

\begin{abstract}
This paper addresses the topic of feminism as it relates to India and Hindu theology. The connection between specifically Hindu theology and Indian culture is first established. There it can be seen that Indian culture has caused changes in Hinduism, often meant to suit the needs of those who changed it. We hypothesise that there is correlation between a lack of feminist narratives seen in contemporary Hinduism and the intentional shifting in religious practices particularly by British colonialists and Indian nationalists in the 19th century to suit their own needs. This raised the question of if there were more examples of shifting in religious practices toward the Brahmin-, cisgender-, and masculine-dominated form we see today. For this we looked into the iconography of Hinduism and found that paintings in particular showed much more diversity in narrative and sometimes even contradicted narratives found in Hindu texts. We make recommendations for better inclusivity in India today based on these findings.
\end{abstract}

Keywords Androgyny, Dalit, Gender, Gender Variance, Homophobia, LGBTQI+, Manusmriti, Queer feminism, Sex, Transgender, Transphobia

\section{Terms}

Androgyny: Existence outside the sex binary. In popular culture this can be a person who is not obviously male or female, but within Hinduism typically refers to a god with a male half and a female half; that is to say, they are one entity but divided vertically in half, with a male side and a female side.

Dalit: These are Hindus who exist outside of the caste system and therefore considered beneath even the lowest caste. A typical translation of the term used to refer to them by higher castes is "untouchables."

Gender: An expression of identity based on cultural norms that normally assign specific behaviours and traits to two defined sexes, giving male and female gender. Gender is a social construct and should not be confused with sex, which is explained below.

Gender Variance: On an individual level, there may not be a defined gender that one person remains with for their entire lives, or perhaps they have a gender that is neither male nor female.

Homophobia: Hatred or fear of, and/or discrimination against, people based on their real or perceived deviation from heterosexual romantic and/or sexual attraction to others.

LGBTQI+: Lesbian Gay Transgender Queer Intersex (and beyond); the abbreviation is meant to be inclusive all people who are non-cisgender and/or non-heterosexual, with each letter of the abbreviation making a distinct category within this broad classification.

Manusmriti: After the Hindu sacred texts were written, a man named Manu claimed that there were religious laws beyond what was contained in them. These were compiled into a book called the Manusmriti, containing prescriptions for proper Hindu practise. Many Hindus today follow his practises.

Queer feminism: an approach to feminism that seeks gender equality for all genders, not just the female gender. Traditionally, feminists only focused on advancing the rights of cisgender females; in contrast, queer feminism is holistic. N.b. many feminists today may be queer feminists without specifically identifying as such; however, those who take this term make clear their position on genders outside of cisgender female.

Sex: Biological indicators that allow for classification of a person into male or female (or other) categorisation based on criteria informed by the scientific community. Whilst less of a social construct, the criteria are based on scientific theory and not simple fact. Determining factors refer to genitalia (vagina is female whilst penis is male) and abundance of testosterone vs. estrogen (testosterone is male whilst estrogen is female). Androgynous people do not easily fit into the two standard categories. N.b. also that gender and sex may differ because they are not intrinsically linked, even if there is a strong coincidence rate in 2018.

Transgender: A person whose gender does not match 
with the sex that they were assigned at birth (the opposite of cisgender); within Hindu theology, this can also refer to gods who transition between sexes, even when they are in their cisgender form.

Transphobia: hatred and fear of, and/or discrimination against, people based on their real or perceived divergence from cisgender gender expression and sex traits.

\section{Introduction}

Both the Bible and Quran have also been used to order women to obey their husbands and to deny them the right to property or political participation. Manusmriti is the most common text that prescribes the code of conduct for Hindus and it is not only disapproving of homosexuality but also specifically condemns female homosexuality in Verses 369 and 370 of Book VIII.[1] Overall, the teachings of Manu are also full of sexism and misogyny. The law book says that a woman should never be given freedom and kept under the control of her father when young, her husband after she is married, and her son if her husband passes away (Verse 151 of Book V).[2] However, Hinduism does not have one source book, unlike the other major world religions. Most orthodox traditional authorities based on Vedanta philosophy consider Brahma Sutra, Upanishads, and Bhagavad Gita to be the three main scriptures for Hindu religious and philosophical thought; unlike Manusmriti, these texts do not explicitly describe the status of women or gender and sexual minorities[3]

\section{Historiography}

Hindu theology is so ingrained in Indian society that any change to Indian culture will necessarily impact Hindu religious practises, whilst the theology of Hinduism to this day dictates the flow of culture in India. Scholarly analysis on the history of Hinduism does not skip out on the intertwined nature of religion and culture in South Asia; however, on the themes pertaining to queer feminism, the literature has thus far been scant. Theologian Rita Gross expresses her thoughts explaining the overall lack of scholarship in her appeal for the Goddess: "As I have demonstrated elsewhere, the patriarchal lens has radically skewed and filtered most of the scholarship done on Greek, Hindu, or any other religious situations. In the case of Hinduism, though the corrective scholarship is still largely undone, the need for it is being recognized, and some beginnings have been made".[4] Essentially, the primary cause of a lack of scholarship has been a bias on behalf of academicians away from feminist narratives in theology the world over.

A question related to this concerns India itself: could there also be a bias on behalf of politicians, priests, and society that could also subvert feminist narratives that have long existed in Hinduism? To answer this question we look to Kedar Vishwanathan, who asserts that India underwent a transformation in its theology in the early 19th Century, initiated (first by the British and then) by nationalists: "The concept of woman symbolized the binary opposition between Indian tradition and British modernity. The nationalists asserted their cultural difference over the British by reforming the one part of their cultural identity they had control over, the spiritual realm and where the metaphorical symbol of the nation - the woman - was placed."[5] This observation has been corroborated by Anirban Das \& Ritu Sen Chaudhury in their work, "The Desired 'One': Thinking the Woman in the Nation", wherein they elucidate the changes made to the institution of marriage, portrayal of Goddesses, and historical perspectives to resist British Colonialism. Already there is evidence that some attempts were made to alter the role of women in Indian society which is intimately linked with "Indian" theology; that is to say, the prevailing religion in India, Hinduism, was modified by nationalists. If adherents to the Hindu faith could transmogrify their religion for secular goals, would it not be possible for other groups of people to create lasting changes to Hindu theology through their actions?

Seeking support for this question, there arose the topic of iconography: did the narratives expressed in Hindu sculptures, paintings, and other art forms differ at times with the textual representation of Hinduism? Gross had an observation of her own to make about a painting of Shiva, one of the major male Gods of Hinduism, looking on at his wife, Kali, in admiration of her war dance on the battlefield:

This behavior contrasts significantly with the text about this incident, which narrates how Kali danced madly out of control on the battlefield until Siva threw himself among the corpses. When Kali danced on him, Brahma pointed out that it was inappropriate for her to tread upon her husband and Kali, rebuked, stopped dancing. The difference between the text, which subtly snubs Kali, and the icon, which catches her at the moment of her exultant dance upon a cooperative, fascinated, non-reproachful Siva, indicates how important the tradition of visual Hinduism is.[6]

So there is at least one example of contradiction between text and art, but even with many sources of evidence, there is still no smoking gun with which to explain the discrepancy. Woodman Taylor's work on the proliferation of paintings as living divine forms (as opposed to statues) had this to say about the effects of this proliferation: "With the circulation of paintings - and later prints and photographs - to larger publics, non-Brahmins and women could acquire and ritually care for their own two-dimensional forms of divinity."[7]

\section{Research Question \& Sub-Questions}

In this paper, we try to answer the following questions: 
1. What are the unique aspects of Hinduism?

2. Are sexism, homophobia, and transphobia fundamentally and universally ingrained into Hinduism?

3. How do the religious texts differ from Hindu art forms?

4. To what extent do the concepts of androgyny and gender variance in Hindu mythology and tradition help in promoting gender inclusion?

\section{Research Methodology}

To better understand the issue of lack of feminist narratives in Hinduism, we would like to look at sources that pertain not only to Hindu texts, but also Hindu iconography - both are important to Hinduism, but the texts seem to only be created and readable by Brahmins of the highest castes, whilst there is a broader spectrum of not only consumers, but producers of religious art. To this end we will look not only at the research conducted by other scholars, but also to compile information about deities and mythical stories within Hindu theology as depicted in the iconography.

The other axis of this paper will be more comparative in nature with regard to Hinduism against other major world religions: if there is a common theme of feminist narratives, or more generally equality in individual intrinsic value, it stands to reason that it is more likely for these themes to exist somewhere in Hindu theology.

After compiling sufficient information about the aforementioned subjects, new sources, mostly within academia, will be sought to help assess why, if there are indeed feminist narratives in either Hindu iconography or in other major world religions, they are not seen as fundamental aspects of Hindu theology today.

\section{Theoretical Framework}

Caste is a function that is both integral of, and now seemingly unique to, the Hindu faith. Through it, a rigid hierarchy dividing the entirety of society is established. Its first major outlining in an authoritative text was in the Manusmriti. In his discussion on the origin of castes, B.R. Ambedkar has argued that Manu merely codified and philosophised systems like caste that existed in Hindu society before his time.[8] However, he also observes that the influence of the laws of Manu is profound and not something to be taken lightly. We would like to extend this argument to sexism, homophobia, and transphobia in Hindu society. Ambedkar has also argued that Hindus do not follow the caste system merely because they are inhuman or wrong-headed, but they follow the caste system because they are ordained to do so by the Shastras (Hindu Scriptures).[9] We seek to advance the argument that the same holds good for sexism, homophobia, and transphobia in Hindu society.

The naturalized law of karma has been used to justify oppression of the marginalized. While this has been critically examined in the context of Buddhism, the Hindu theory of karma based on souls is even more problematic and this was in fact a motivation for Ambedkar to convert to Buddhism [10].

\section{Hypothesis}

Feminist narratives are largely missing from modern Hinduism due to obfuscation, cooptation, cultural transmogrification, and historiographical bias.

\section{Unique aspects of Hindu theology}

\section{(i) Plurality of source Books and deities}

The first challenge in trying to understand the theological position of Hindus is that there is no one scripture or authority for Hinduism. Hindus have diverse traditions, customs, scriptures, and religious practices to the extent that a question can be asked if there are even enough shared values to say Hinduism is one religion. The Christians accept the Bible as their scripture and the Muslims the Quran as their scripture, but for Hinduism there is no one book that can boast the same respective status. Some might say that Bhagavad Gita is a fundamental Hindu scripture but a religious Hindu does not have to read a verse of the Gita to practice their religion as there are several other core religious texts as well. While it looks like this is a great thing because if any one scripture is biased against women or gender minorities, we are not bound by it, it also means that theological engagement with Hindu religious groups is all the more challenging because even if we present a story of acceptance and inclusivity from one source it may not appeal to another.

Most authorities would consider Manu the first and most important law book for Hindus and it is clearly misogynist, sexist, homophobic, and transphobic. The additional challenge is that we cannot dismiss these rules prescribed by Manu as symbolic because the only purpose of the book is to give laws for human society: unlike the Bhagavad Gita, Bible, or Quran, Manu does not have stories that are full of symbolic meaning and open to interpretation. The only argument we can make is that it is a Smriti, which in traditional Hindu theology is a secondary scripture and not a Shruthi, the basic and immutable Vedic texts in Hindu theology like the Upanishads. So, we can argue that Manu is outdated. However, it would still fail to cut ice with traditional Hindus because Manu has himself laid out the rules of interpretation which have no place for rational thinking. This is clearly explained by Dr. B. R. Ambedkar who in his monumental work, Annihilation of Caste observes: "According to this rule, rationalism as a canon of interpreting the Vedas and Smritis is absolutely 
condemned. It is regarded to be as wicked as atheism, and the punishment provided for it is excommunication. Thus, where a matter is covered by the Veda or the Smriti, a Hindu cannot resort to rational thinking" [11].

Transgender communities have their own customs and traditions and worship gods like Angalamman. This has resulted in a hierarchy or caste system even among the gods with not only more money and wealth poured into the shrine of a prestigious god like Venkateswara in Tirupati, but also these gods enjoying a higher social status compared to a god like Mariamman or Angalamman worshiped by the marginalized sections of the society.[12]

There are examples of fierce and powerful feminine gods like Mariamman but they do not enjoy the same prestige and status like the gods of the dominant castes. The prestigious temples like the shrine of Krishna in Guruvayoor or the Jagannath temple in Puri have controversial entry regulations that state that only orthodox Hindus are allowed to enter. Even the former Prime Minister of India, Indira Gandhi, was denied entry to Jagannath temple as she married a Parsi.[13] While such regulations affect everyone, they affect women and gender minorities disproportionately.

\section{Theological basis for unequal creation of human}

The next issue in dealing with Hindu religious attitudes to queer identities is that social hegemony is theologically encoded in Hinduism. Most religions have for their ideal, equality of humankind. For example, Christianity preaches that God created man in his own image. Although we have a problematic narrative of Eve being created from the rib of Adam, another reading of the Genesis says men and woman were all created equally by God. In essence, Islam also teaches us that all are equal in the eyes of Allah. Buddhism does not talk about God but certainly talks about equality for all human beings. This is not to say that in practice, the followers of these religions have ensured equality for all. The reality is far from that. Christianity was used to justify slavery and deny women their fundamental rights. In countries like the United States the major objections to basic LGBTQI+ rights like marriage equality and access to restrooms for trans* persons all come from orthodox Christian ideology. However, in its most basic and essential form, the theology of most religions is based on the premise of equality of all.

In its dominant discourse, Hinduism seems to be an exception to this trend. The most popular account of creation of human beings is some variation of the story told in Purusha sukta, which is hymn 10.90 of the Rigveda. Here are the verses about creation of caste as translated by Swami Krishnananda: "The Brahmana (spiritual wisdom and splendour) was His mouth; the Kshatriya (administrative and military prowess) His arms became. His thighs were the Vaisya (commercial and business enterprise); of His feet the Sudra (productive and sustaining force) was born.”[14]
While it can be argued that both the mouth and the feet are equally important for a human being to function, it is also true that the feet can never aspire to become the mouth. The fallacy of equality in such a setup is similar to that in the "separate but equal" doctrine which was used to justify apartheid. Even after the end of apartheid in South Africa, former President and Nobel Peace Prize winner F. W. de Klerk maintained that not all aspects of apartheid were "morally repugnant", and that there was "merit" in the notion of ethnic groups living apart but that in South Africa, the experiment had not worked.[15] In a similar manner, Hindu theology has been historically used to justify every form of social hegemony like gender inequality, caste system, and marginalization of individuals with alternative sexuality. The problem is that everyone is given a space in this setup, but by using analogies like the human body, those who are marginalized are encouraged to believe that while it might look like they have a lower status actually their status is not inferior. Shudras are repeatedly told that they are like the feet of the body and should do all the dirty work but they are in no way inferior to others. It is irony that religious traditions encourage people to fall at the feet of holy men but also anything touched by the feet of common people is considered dirty. The marginalized castes are encouraged to make sacrifices for the greater good of society but tactically dissuaded from demanding their rights. The same happens to women and queer communities as well. Women are made to believe that pleasing their husband - even if it means somehow fulfilling his unreasonable demands - is as noble as offering worship to God. Transgender people are considered holy and invited to bless others. However, as observed by social worker Noori: "Even when Hijras go for blessing ceremony or badai, parents tell their children to hide and that instills fear in them. If we sensitize them in schools, they will grow up to understand Hijras are a part of society. Just like there is male or female, there is a third gender."[16]

In Hindu culture and tradition, Dalits, women, and transgender people are portrayed as either divine beings capable of blessing others or demoniacal beings whose curses would ruin the world, but never as human beings who are equal participants of the social order. If a certain group of people are told that they don't have any rights or that their work is inferior, it is bound to spark a revolution like communist revolution of Soviet Russia or the movement for abolishing slavery in the United States. However, the problem with the Hindu social setup is that the oppressed are made to believe that they are equal although they obviously have unequal power and privilege. Through religious teaching, people are indoctrinated to think that suffering is a virtue.

\section{Hindu theological perspectives on gender and sexuality}

(i) Literal Interpretation vs. Metaphorical and Anecdotal Interpretation of Sacred Text 
While Vedic epistemology recognizes that knowledge can be gathered by what is seen or by use of reasoning, it places undue importance on scriptural traditions (agama pramana).[17] According to orthodox Hindu teaching, the ultimate source of knowledge, not only about God and heavenly things but even about the world we live in are the Vedas. Most modern religions have moved away from the perspective that the scriptures are literally true in or that they have the aim of educating us about the facts of the physical world we live in [18]. For example, recently Pope Francis made a statement that Big Bang Theory and evolution are not in contradiction of the act of divine creation and should be accepted and studied alongside the Bible [19].

While the concept of purity and pollution is of paramount importance to the dominant castes, this perspective is not shared by all Hindus:

"You know, I have become old but when my wife is at her menses she is allowed to stay in a corner and rest. I and my son cook for ourselves. We do not let her work. We consider her untouchable at that time. If she is not given rest, she will not be in a good condition. (Apffel-Marglin and Misra 1991a, 35).”[20][21]

\section{(ii) Subversion of resistance to oppression}

Since the focus of Hindu theology is on becoming better in the next life, there is not much incentive to fight against injustice in this life. People are told that if today they experience stigma and discrimination as a Dalit, woman, or a queer person, they should bite the bullet and patiently continue to serve the society because by earning merit (punya) they can be reborn as a male Brahmin in next life, which will have all power and privilege.

\section{(iii) Hindu iconography vs. scriptures}

Even today, religious institutions like Sankara Mutt (the monasteries founded by Adi Sankaracharya and associated with the five holy shrines of India) continue to practice blatant discrimination based on caste and gender but get away with it by disguising such evil practices as noble religious traditions. For example, a woman or a person from the oppressed castes does not have equal opportunity to study the Vedas in these institutions. Women and transgender people are also not allowed to study the most prestigious scriptures. With only the dominant-caste men being able to write or even read scriptures, it comes as no surprise that the narratives contained therein have a bias toward those same two exact demographics. This also often extends to statues, as they are considered living gods; as such, only Brahmin men are entitled to care for them. It is in other forms of iconography - namely, things like paintings - that there is permissible engagement, both in creation, but in caretaking and ownership, allowing all castes and gender identities to participate in every stage of the iconographical process. There may not be a prevailing narrative in such a broad genre, but that in itself is telling: it is here that one can see narratives with prominent non-male depictions. A few examples have been mentioned above, but there are more. For example, the evolution of depictions of Durga, a goddess originally known for slaying the Buffalo Demon: "In many of the icons the Buffalo Demon recedes in importance and all the stress is on Durga herself, masterfully standing on his head, as in a relief in use today in numerous South Indian temples. This emphasis on Durga as deity has given rise to a very widespread and popular icon of Durga riding her lion or tiger, displaying her attributes and dispensing boons with no reference whatsoever to the Buffalo Demon."[22] Among the non-Brahmin castes it is possible to see more female prominence in terms of cosmic balance as well, with the traditional notions of masculine as activity and feminine as passivity being reversed in Tantric Hinduism and known as Maya-Sakti.[23]

Iconography can also have divergent perspectives on a single issue. Although there is an association between gender and the side expressing it in androgynous merging of two gods, with the left reserved for women and the right for men, there are also works that illustrate the opposite. The most noteworthy, perhaps, is of the portrayal of Shiva, one of the three most prominent of the gods, and his merging with Shakti.[24] Female deities are often portrayed somewhat more one-dimensionally than their male counterparts. Within iconography, the roles of goddesses can expand beyond the limitations afforded to them by the texts, creating a discrepancy between the books and the art. Lakshmi, through artistic depictions and mainly through paintings where she has come to patron other aspects of life, has taken the primary position in Deepavali, the New Year's Festival of Lights, where she is given the lead role as the Goddess of Wealth.[25]

\section{(iv) The male bias in androgyny}

While there are both masculine and feminine divine entities, the feminine ones are always subsumed into the masculine and not the other way round. For example, Shiva, the god of destruction in Hindu theology, is called popularly "Ardhanarishvara", which literally means half-woman. However, there is no such popular term to talk about Parvathi, his consort, as a half-man God. Vishnu, the Hindu god of protection, took incarnation as Mohini, a female form, to slay a demon, and subsequently mated with Shiva and had a child called Ayyappa. There is no similar popular story of a female god turning male and mating with another woman. Even today, transgender women have greater acceptance in traditional society, compared to trans men, lesbian or bisexual women.

Ironically till date, women between the period of menarche and menopause are not allowed into the primary shrine of Ayyappa in Sabarimala, Kerala, who was himself born in a very unconventional marriage between male and transgender gods. The issue has been even taken to the Supreme Court of India whose judges have in one hearing 
of the case observed that unless the temple authorities have a valid reason to prevent women from entering the shrine such discrimination based on gender is unconstitutional [26]. The final verdict has not yet been given on this case.

\section{Conclusions}

India's societal structure is intricately linked with the Hindu religion. With the changes made to Hindu religious practices during the Colonial Era and Vedic affirmation of a bias toward texts that have a Brahmanical favouritism over iconography, there exists sexism, casteism, homophobia, and transphobia in the essence of daily life. There exist religious interpretations that are more inclusive and they are expressed mostly in forms that are not monopolized by the dominant male Brahmins, namely through visual art forms, especially paintings. Because the conventional practice of Hinduism currently hinges on the whims of the most privileged in society, it seems to follow that the way to overcome the inequalities is to facilitate the decentralisation of control over rites and scriptures. Due to karma, many do not strive to improve in this lifetime; however, why should they have to wait for a better life? To help facilitate this, more study should be conducted of ancient religious items to increase awareness about empowering narratives as well as promoting inclusive policies and decision making.

\section{Recommendations}

There is an urgent need to study queer and feminist Hindu theological perspectives, which would help address the following issues:

- Sexism, misogyny, homophobia and transphobia that is the direct result of dominant narrative of Hindu theology.

- Low representation of women in religious institutions

- Exclusion of marginalized castes, women, and transgender people from mainstream society.

\section{REFERENCES}

[1] Bühler, George (Translator). Manusmriti, 1886, Ch 8:369-70.

http://www.sacred-texts.com/hin/manu/manu08.htm

[2] Patwari, Hirday N. "The Status Of Women As Depicted By Manu In The Manusmriti”, 2011. http://nirmukta.com/2011/08/27/the-status-of-women-as-d epicted-by-manu-in-the-manusmriti/

[3] Wikipedia. "Prasthanatrayi" Last edited: 18 March, 2018 https://en.wikipedia.org/wiki/Prasthanatrayi
[4] Gross, Rita M. "Hindu Female Deities as a Resource for the Contemporary Rediscovery of the Goddess", 1978, pg. 273. http://www.jstor.org/stable/1463798

[5] Vishwanathan, Kedar. "Aesthetics, Nationalism, and the Image of Woman in Modern Indian Art", 2010, pg. 3. https://docs.lib.purdue.edu/cgi/viewcontent.cgi?article $=15$ $94 \&$ context $=$ clcweb

[6] Gross. "Hindu Female Deities", pg. 283. http://www.jstor.org/stable/1463798

[7] Taylor, Woodman. "Agency and Affectivity of Paintings: The Lives of Chitrajis in Hindu Ritual Contexts", 2005. https://www-tandfonline-com.proxy-ub.rug.nl/doi/abs/10.2 $752 / 174322005778054294$

[8] Ambedkar, B.R. "Castes in India: Their Mechanism, Genesis and Development", 1916. http://www.columbia.ed $\mathrm{u} /$ itc/mealac/pritchett/00ambedkar/txt_ambedkar_castes.ht $\mathrm{ml}$

[9] Ambedkar, B.R. "The Annihilation of Caste", 1935, pg. 30. http://ccnmtl.columbia.edu/projects/mmt/ambedkar/web/re adings/aoc_print_2004.pdf

[10] Wright, Dale S. "Critical Questions Towards a Naturalized Concept of Karma in Buddhism", 2011, pg. 85. http://blogs.dickinson.edu/buddhistethics/files/2011/01/wri ght01.pdf

http://shodhganga.inflibnet.ac.in/bitstream/10603/165991/ 9/09 chapter\%204.pdf

[11] Ambedkar, "Annihilation of Caste", pg. 34.

[12] Overview of World Religions, "Devotion to Mariamman", Philosophy, Theology, and Religion (University of Cumbria), Accessed 10 March, 2018, http://www.philtar.ac.uk/encyclopedia/hindu/ascetic/maria m.html

[13] Bhubaneshwar. "Controversies over Jagannath Temple's entry rules", 2012. http://www.ndtv.com/bhubaneshwar-ne ws/controversies-over-jagannath-temples-entry-rules-4953 14

[14] Krishnananda, Swami. "Daily Invocations", Accessed 11 March, 2018, pg. 63.

http://www.swami-krishnananda.org/invoc/Daily_Invocati ons.pdf

[15] Laing, Aislinn. "FW de Klerk: Not all aspects of apartheid 'morally repugnant'", 2012. http://www.telegraph.co.uk/ne ws/worldnews/africaandindianocean/southafrica/9260637/ FW-de-Klerk-not-all-aspects-of-apartheid-morally-repugna nt.html

[16] Deb, Sutapa. "India matters: A judgment in gender", 2014 http://www.ndtv.com/india-news/india-matters-a-judgeme nt-in-gender-563583

[17] New World Encyclopedia. "Pramana", 2008 http://www.newworldencyclopedia.org/entry/Pramana

[18] Ruthven, Malise. "Fundamentalism: The Search for Meaning" (Preface), 2004, pg 37. https://books.google.co.in/books/about/Fundamentalism T he_Search_For_Meaning.html?id=NHNIRveDsXMC\&pri $\mathrm{ntsec}^{-}=$frontcover\&source $=\mathrm{kp}$ read button\&redir esc $=\mathrm{y} \# \mathrm{v}$ $=$ onepage $\& \mathrm{q} \& \mathrm{f}=$ false 
[19] Davies, Lizzie. "Pope Francis: evolution and creation both right",

2014. https:/www.theguardian.com/world/2014/oct/28/pope-say s-evolution-and-creation-both-right

[20] Sharma, Arvind. Goddesses and Women in the Indic Religious Tradition, 2005, pg. 67.

[21] Patel, Kartikeya C. "Women, Earth, and the Goddess: A Shakta-Hindu Interpretation of Embodied Religion", 2010, Pg. https://onlinelibrary.wiley.com/doi/full/10.1111/j.1527-20 01.1994.tb00650.x

[22] Gross, Pp. 280-1.
[23] Ibid., pp. 284-5

[24] Kalidos, Raju. "Vāmacāra Viṣnu in Hindu Iconography A Problem in Sociological Values", 1994 pg. 276. http://www.jstor.org/stable/29757154

[25] Taylor, Woodman. "Agency and Affectivity of Paintings", pg. 216.https://www-tandfonline-com.proxy-ub.rug.nl/doi/ abs/10.2752/174322005778054294

[26] Rajagopal, Krishnadas. "Do you have a constitutional right to prevent women's entry at Sabarimala? SC to Devaswom", 2016.

http://www.thehindu.com/news/national/Do-you-have-a-co nstitutional-right-to-prevent-womens-entry-at-SabarimalaSC-to-Devaswom/article13995792.ece 